\title{
Food Forensics in the Human and Pet-Food Industry: Use of a Simple Technology to Identify Commercially Important Species of Kangaroos from Western Australia
}

\section{Peter B S Spencer ${ }^{1 *}$ and Kevin Marshall ${ }^{2}$}

${ }^{1}$ School of Veterinary and Life Sciences, Murdoch University, Western Australia 6150, Australia

${ }^{2}$ Department of Parks and Wildlife, 201 Foreshore Drive, Geraldton, Western Australia 6660, Australia

\begin{abstract}
Kangaroos are internationally recognised and iconic wildlife. There are four species that are commercially harvested for human and pet meat in an industry worth more than US $\$ 150$ million per year. Highly regulated controls govern the number, and the species that can be removed each year as many species undergo natural cycling in population number in response to stochastic fluctuations, such as rainfall (where populations generally increase) and periods of drought (decline in population numbers).

At times when populations are too low, seasonal closures do not allow the harvesting of those species. This is when illegal killing is most detrimental and there is currently no method or comparative database to identify commercial game-meat kangaroo species.

Here we generated a simple and discriminatory test that uses sequence data from mitochondrial DNA capable of differentiating amongst all the largest species of kangaroos (the wallaroo, western grey, eastern grey, and red kangaroo) in Australia.
\end{abstract}

We present these data and we also include 18 suspected kangaroo sample seizures that formed the basis for the unambiguous, simple and relatively fast identification of seized kangaroo meat samples.

Keywords: Wildlife forensics; Kangaroo; Wallaby; Illegal game; Food authenticity; Species identification

\section{Introduction}

The kangaroos and wallabies are iconic fauna that are immediately identifiable with the Australian landscape. The group belong to the superfamily Macropodoidea (or macropods), which contain about 45 living species in Australia [1]. These species are found naturally in the wild only in Australia and New Guinea, although some feral populations have been introduced in New Zealand, Great Britain and Hawaii. Of these, four are commercially harvested in an internationally recognised sustainable industry (red kangaroo, common wallaroo, western and eastern grey kangaroos; [2]). None of the commercial species is threatened or endangered and the red kangaroo remains the sole example of a national emblem that is harvested for human consumption. The Red kangaroo, Eastern grey and Western grey kangaroo are the most abundant species on mainland Australia and make up over 90 per cent of the commercial harvest. In the harvested areas, and depending on seasonal conditions, their combined population sizes have fluctuated between 15 and 50 million animals over the past 20 years. The intensity of harvest is relative to the population size and determined on a quota basis that is reviewed annually (see: http://www. environment.gov.au/biodiversity/trade-use/). These quotas are set on the basis of population size/trends and long-term climate predictions. The proportion of animals taken adopts a precautionary principle as conservation of the species remains the foremost consideration. This approach ensures that the harvesting of kangaroos has, and is, managed in an ecologically sustainable way.

Over $99 \%$ of the commercial kangaroo harvest occurs in the arid grazing rangelands, some 2 million $\mathrm{km}^{2}$ [3]. As with any natural population, all species of kangaroos undergo natural fluctuations in population abundance, generally in response to rainfall $[4,5]$. The Wildlife Protection (Regulation of Exports and Imports) Act of 1982 regulates the exports and imports of kangaroo products. In addition, as a signatory to the Convention on International Trade in Endangered Species (CITES), Australia has the responsibility to regulate the exports and imports (and harvest) of all native animals and plants including kangaroos. Like many wildlife products, once the product has been processed (into packing/shipping containers), it is extremely difficult (if not impossible) to identify the species, or origin of the sample simply by inspection of the product. Forensic investigations can offer an important service in the regulation of illegal killing as well as fraudulent mis-description of end food products. This is important because consumers are demanding clear and accurate information for the food they buy ('truth in labelling'), be those for conservation, religious, social, health or lifestyle reasons [6]. Furthermore, in any wild harvest there is also a conservation concern, as overharvesting may ultimately lead to the decline or even complete collapse of the industry as has been seen in some fisheries. As such, an important function of wildlife protection authorities is to make sure that illegal (over)harvesting does not occur. To do this, authorities need to be equipped with indisputable tools that would allow them to regulate

${ }^{*}$ Corresponding author: Peter B S Spencer, School of Veterinary \& Life Sciences, Murdoch University, 90 South Street, Murdoch, Perth, Western Australia 6150 Australia, Tel: (+61-8) 9360 2489; Fax: (+61-8) 9360 6303; Fax: +45 35326085 E-mail: P.Spencer@murdoch.edu.au

Received June 27, 2013; Accepted August 22, 2013; Published August 27, 2013

Citation: Spencer PBS, Marshall K (2013) Food Forensics in the Human and Pet-Food Industry: Use of a Simple Technology to Identify Commercially Important Species of Kangaroos from Western Australia. J Forensic Res 4: 190. doi:10.4172/2157-7145.1000190

Copyright: (C) 2013 Spencer PBS, et al. This is an open-access article distributed under the terms of the Creative Commons Attribution License, which permits unrestricted use, distribution, and reproduction in any medium, provided the original author and source are credited. 
and detect discrepancies within the product that is being regulated. The harvesting of kangaroos is an example of such an industry. Furthermore, given the significant differences between the pricing of premium versus substandard and inferior substitutes, it is also an increasing concern that there is 'truth in labelling'.

For investigative work with kangaroos, we were unable to identify an existing dataset with sufficient fine-scale resolution to identify the macropods to species level. As such, here we describe a dataset generated from a range of commercial and other species of macropods for the express purpose of forming the basis of a database that can be used to identify a seizure sample to a known species of origin.

\section{Case samples}

A single small meat sample was collected from 15 boxes from a commercial operation by the Department of Environment and Conservation, WA. They were labelled with only a reference number on each sample (there were no identifying features) and sent to the DNA laboratory as a blind test (labelled with a laboratory identification number and called "blind sample"; Figure 1).

\section{Materials and Methods}

Tissues from 10 taxa from a range of macropod taxa (and localities) were sampled for DNA analysis (Table 1). The DNA was sourced from either frozen specimens, liver or freshly obtained tissue (ear notches) from specimens collected as a result of accidental road kills, including representatives from the four most important commercial species (Table 1).

DNA extraction, mtDNA amplification and sequencing analysis was carried out following $[7,8]$. Briefly, DNA was extracted from a small ( $<20 \mathrm{mg}$ ) sampleand a partial section (411 base-pairs) of the cytochrome $\mathrm{b}(\mathrm{cyt} \mathrm{b})$ region of mtDNA was amplified using the polymerase chain reaction (PCR) with $1 \mathrm{U}$ of Tth Plus DNA polymerase (Fisher Biotech), in the presence of approximately $100 \mathrm{ng}$ of template DNA, $1.0 \mu \mathrm{M}$ of each primer, $200 \mu \mathrm{M}$ dNTPs, $1.5 \mathrm{mM} \mathrm{MgCl}_{2}$, and $1 \mathrm{X}$ polymerase buffer (67 mMTris-HCl; $\mathrm{pH} 8.8,16 \mathrm{mM}\left[\mathrm{NH}_{4}\right]_{2} \mathrm{SO}_{4}, 0.45 \%$ Triton X-100 and $0.2 \mathrm{mg} / \mathrm{ml}$ Gelatin) supplied by the manufacturer in a total volume of $40 \mu \mathrm{l}$. Primers for the cytb region were based on a universal primers L14724 (5' CGAAGCTTGATGAAAAACCATCGTTG 3') and H15149 (5'CCCTCAGAATGATATTTGTCCTCA 3'; [9]). After an initial 5 min denaturation step at $94^{\circ} \mathrm{C}$, the reaction tubes $(40 \mu \mathrm{l})$ were exposed to 25 cycles of the following protocol: $30 \mathrm{sec}$ at $94^{\circ} \mathrm{C} ; 45 \mathrm{sec}$ at $50^{\circ} \mathrm{C}$; $30 \mathrm{sec}$ at $72^{\circ} \mathrm{C}$, followed by a final extension step of $10 \mathrm{~min}$ at $72^{\circ} \mathrm{C}$. Both the forward and reverse strands were sequenced on an3730 ABI automatic sequencer with one of the primers used for PCR.

DNA chromatograms were interpreted using the program MEGA 5.2 [10]. Mitochondrial sequences were aligned by eye. Phylogenetic relationships between taxa were analysed using a full heuristic search with the aid of MEGA [10]. In addition, phylogenetic analyses were also performed using Bayesian inference [11]. Support for all tree topologies were tested by bootstrap resampling with 1000 replicates (to ensure strong support for any resulting trees). All sites were assumed to have evolved at the same rate and Maximum Parsimony was used to analyse the data using the Kimura 2-parameter (K2P) model, as suggested by Model test [12].A pair wise percentage sequence divergence matrix was generated using MEGA based on the K2P model. The distribution of most parsimonious tree (relative to the distribution of 1000 randomly produced topologies) was also calculated ( $g_{1}$ statistic), to determine if the resulting topologies were due to strong phylogenetic signal or 'molecular noise' [13]. Bayesian inferences were conducted using
MrBayes v3.1.2 (Huelsenbeck and Ronquist, 2001). The posterior probabilities were calculated using four independent Markov chains run for 10,000,000 Metropolis-coupled MCMC generations, with tree sampling every 1000 generations and a burn-in of 5000 trees [11].

\section{Results}

We found that the approach we took was able to unambiguously place species of kangaroo into unique tree topologies. As such we could place strong confidence (bootstrap values of greater than 97\%) on unambiguously identifying a particular species of kangaroo. Phylogenetic analyses performed on $411 \mathrm{bp}$ of the cytochrome $b$ gene from 40 individuals included representatives of the commercial species (Table 1) and were phylogenetically informative. There were 287 constant characters, 64 variable characters were informative for

\begin{tabular}{|c|c|c|}
\hline $\begin{array}{l}\text { Species } \\
\text { Common name }\end{array}$ & Sampling location & $\begin{array}{l}\text { Sample No. } \\
\text { identification }\end{array}$ \\
\hline \multirow[t]{9}{*}{ Macropus rufus } & Location not given & U87136† \\
\hline & Geraldton, WA & 04-012 \\
\hline & Dongara, WA & 04-014 \\
\hline & Northampton, WA & 04-015 \\
\hline & Northampton, WA & 04-016 \\
\hline & Yalara, Northern Territory & 04-017 \\
\hline & Greenvale, Queensland & AY099270 \\
\hline & Meekathara, WA & 04-01 \\
\hline & Location not given & U87138 \\
\hline \multirow{6}{*}{ M. robustus } & Lynd Station, Queensland & $\mathrm{Y}_{10524^{\dagger}}$ \\
\hline & Location not given & NC001794† \\
\hline & Dongara, WA & 05-012 \\
\hline & Dongara, WA & 05-015 \\
\hline & Northampton, WA & 05-016 \\
\hline & Mt Keith, WA & 05-019 \\
\hline \multirow{7}{*}{$\begin{array}{l}\text { M. fuliginosus } \\
\text { Western grey kangaroo }\end{array}$} & Geraldton, WA & 04-006 \\
\hline & Dongara, WA & 04-007 \\
\hline & Mullewa, WA & 04-008 \\
\hline & Mullewa, WA & 04-009 \\
\hline & Dongara, WA & 04-010 \\
\hline & Mt Cooke, WA & 04-011 \\
\hline & Townsville, Queensland & AY099271 ${ }^{\dagger}$ \\
\hline \multirow{4}{*}{$\begin{array}{l}\text { M. giganteus } \\
\text { Eastern Grey kangaroo }\end{array}$} & Black Rock, Queensland & AY099267 ${ }^{\dagger}$ \\
\hline & Location not given & U87137 \\
\hline & Queensland & DQ019618 ${ }^{\dagger}$ \\
\hline & Newcastle, N.S.W. & 13-EGY1-3 \\
\hline \multirow{3}{*}{$\begin{array}{l}\text { M. eugenii } \\
\text { Tammar wallaby }\end{array}$} & Garden Island, WA & AY099280 \\
\hline & Perth Zoo, WA & AY237226 ${ }^{\dagger}$ \\
\hline & Garden Island, WA & AY099281 ${ }^{\dagger}$ \\
\hline $\begin{array}{l}\text { M. irma } \\
\text { Western Brush wallaby }\end{array}$ & Tuttaning, WA & AY099272 \\
\hline $\begin{array}{l}\text { M. rufogriseusbanksianus } \\
\text { Red necked wallaby (mainland) }\end{array}$ & Unknown mainland location & AY237228 ${ }^{\dagger}$ \\
\hline $\begin{array}{l}\text { M. rufogriseusrufogriseus } \\
\text { Red necked wallaby (Tasmania) }\end{array}$ & Tasmania & AY237227 ${ }^{\dagger}$ \\
\hline $\begin{array}{l}\text { M. parryi } \\
\text { Whiptail wallaby }\end{array}$ & Location not given & AY237229' \\
\hline $\begin{array}{l}\text { Aepyprymnusrufescens } \\
\text { Rufous rat kangaroo }\end{array}$ & Black Rock, Queensland & AY099266 ${ }^{\dagger}$ \\
\hline
\end{tabular}

Table 1: Sampling locations of species of macropods used as references samples in this study. The first four species of macropods in particular (red kangaroo, common wallaroo, western and eastern grey kangaroos) from the main varieties that are commercially harvested in Western Australia (WA). The remainder of the species are smaller non-commercial species weighing $>5 \mathrm{~kg}$ [1]. These were included in this study because they could potentially be substituted as meat. The ${ }^{\dagger}$ indicates a sequence was obtained from GenBank. 


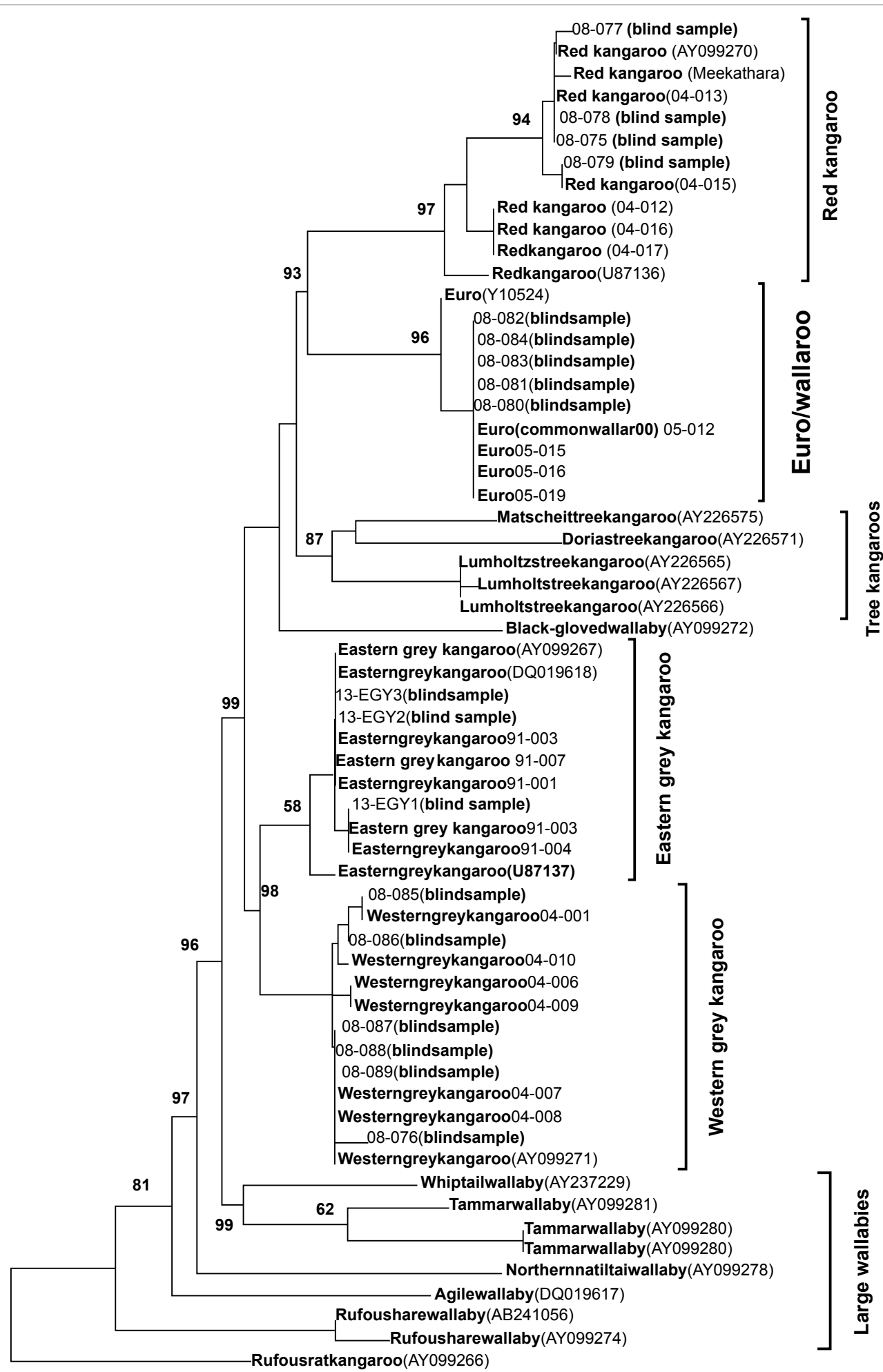

$\longmapsto .01$

Figure 1: Relationships of 61 specimensfrom kangaroos and wallabies that would be considered suitably large to take for the commercial industry. The phylogeny was inferred using the Neighbor-Joining method [10]. The optimal tree with the sum of branch length $=0.7499$ is shown. The percentage of replicate trees in which the associated taxa clustered together in the bootstrap test (1000 replicates) are shown next to the branches [21]. The tree is drawn to scale, with branch lengths in the same units as those of the evolutionary distances used to infer the phylogenetic tree. The evolutionary distances were computed using the Maximum Composite Likelihood method [10] and are in the units of the number of base substitutions per site. All positions containing gaps and missing data were eliminated from the dataset (complete deletion option). There were a total of 249 positions in the final data. Numbers in brackets are from GenBank and all other numbers are from our laboratory. 
Citation: Spencer PBS, Marshall K (2013) Food Forensics in the Human and Pet-Food Industry: Use of a Simple Technology to Identify Commercially Important Species of Kangaroos from Western Australia. J Forensic Res 4: 190. doi:10.4172/2157-7145.1000190

Page 4 of 4

parsimony. The heuristic search resulted in a single parsimonious tree with a consistency index of 0.75 (Retention index $=0.91$ ). The $g_{1}$ statistic, calculated from 1000 randomly sampled trees $(-0.500)$ was significantly skewed to the left, suggesting that the result was a result of strong phylogenetic signal and not simply due to random noise in the DNA sequences (Hillis and Huelsenbeck) [13]. The tree produced from the heuristic, Bayesian (not shown) and neighbour joining methods (Figure 1) produced trees with concordant topologies, suggesting the presence of four strongly supported (68-99\% bootstrap) and highly divergent lineages of macropods. Sequence differences between macropods were near 10\% (mean 12.7\%; range $8.7-18.6 \%$ ). This contrasted with less than $3 \%$ sequence variation within each species-group.

\section{Case samples}

The small seizure samples (of unknown species identity) resulted in their clear association with particular macropod species and claded within the known-species groups in the final phylogenetic tree (Figure 1). Each sample clustered (with high bootstrap re-sampling) within an existing kangaroo group and made the species identification of each sample relatively straightforward.

\section{Discussion}

An increasing number of wildlife forensic cases are now utilising the resources provided by DNA technology and there is an increasing amount of data available for comparative and investigative work $[6,14,15]$, including databases containing sequences for a wide variety of species [16,17], which can be used to investigate smuggling $[18,19]$ and food identification $[15,20,21]$. Despite this, none have been able to identify commercially harvested kangaroos with the sample resolution that we present in this study. The results of this study enable specific identification of persecuted kangaroo species.

One of our original aims was to utilise PCR, and to then adapt a user friendly RFLP approach so that the technology could easily be adapted to other laboratories, without the need for complicated and costly new technology. However, there were no cost effective restriction sites within the fragments generated hence direct sequencing was used for species identification. Given the relatively fast and cheap options of DNA sequencing ( US\$4/sample) this was not considered an unrealistic approach to any forensic investigation.

Without the benefit of an entire carcass it would be impossible to assign a kangaroo to species based only on a sample of meat from a seizure. While this evidentiary material would only form a part of any investigation, we suggest that this study demonstrates that it can be a key component in its definitive (confirmatory) identification. We have also successfully extracted DNA from samples stored (dried) for nearly 20 years, suggesting that investigations can proceed long after a sample is taken, however this will be highly influenced by the storage condition of the sample. This study was specifically aimed at determining whether a molecular approach could be used to identify meat samples seized from kangaroo, specifically a sample that was taken from a commercial operation and/or harvesting site. Not surprisingly, we could easily extract DNA and sequence those samples to obtain a species-specific identity. From these sequences we were able to unambiguously distinguish macropods from nine other marsupial species, and particularly the red, eastern, western grey kangaroos and the euro, which would be impossible to identify by sample morphology alone. The identification of kangaroos is also possible using this approach from other sources, such as in forensic cases involving blood splatter, faeces [7] or from highly degraded samples [8].

\section{Acknowledgement}

We are very grateful for the comments and improvements made to the original manuscript. This study received financial support from the Department of Environment and Conservation, Australian Academy of Sciences and Murdoch University.

\section{References}

1. Van Dyck S, Strahan R (2008) The mammals of Australia. New Holland Publishers, Sydney, Australia.

2. Grigg GC, Pople AR (2001) Sustainable use and pest control in conservation kangaroos as a case study. In Reynolds J, Mace G, Redford K, Robinson J (editors) Conservation of Exploited Species. Cambridge University Press: Cambridge.

3. Pople A (2004) Population monitoring for kangaroo management. Aust Mammal 26:37-44

4. Jonzen N, Pople AR,Grigg GC, Possingham HP(2005) Of sheep and rain large-scale population dynamics of the red kangaroo.J AnimEcol 74: 22-30.

5. McCarthy MA (1996) Red kangaroo (Macropus rufus) dynamics: effects of rainfall, density dependence, harvesting and environmental stochasticity. JAppl Ecol 33: 45-53.

6. Woolfe M, Primrose S (2004) Food forensics: using DNA technology to combat misdescription and fraud. Trends Biotechnol 22: 222-226.

7. Alacs E, Alpers DL, deTores PJ Dillon M, Spencer PBS (2003) Identifying the presence of Quokkas (Setonix brachyurus) and other macropods using cytochrome $b$ analyses from faeces. Wildl Res 30: 41-47.

8. Spencer PB, Schmidt D, Hummel S (2010) Identification of historical specimens and wildlife seizures originating from highly degraded sources of kangaroos and other macropods. Forensic Sci Med Pathol 6: 225-232.

9. Kocher TD, Thomas WK, Meyer A, Edwards SV, Pääbo S, et al. (1989) Dynamics of mitochondrial DNA evolution in animals: amplification and sequencing with conserved primers. Proc Natl Acad Sci U S A 86: 6196-6200.

10. Tamura K, Dudley J, Nei M, Kumar S (2007) MEGA4: Molecular Evolutionary Genetics Analysis (MEGA) software version 4.0. Mol Biol Evol 24: 1596-1599.

11. Huelsenbeck JP, Ronquist F (2001) MRBAYES: Bayesian inference of phylogenetic trees. Bioinformatics 17: 754-755.

12. Posada D, Crandall KA (1998) MODELTEST: testing the model of DNA substitution. Bioinformatics 14: 817-818.

13. Hillis DM, Huelsenbeck JP (1992) Signal, noise, and reliability in molecular phylogenetic analyses. J Hered 83: 189-195.

14. Branicki W, Kupiec T, Pawlowski R (2003) Validation of cytochrome b sequence analysis as a method of species identification. J Forensic Sci 48: 83-87.

15. Teletchea F, Bernillon J, Duffraisse M, Laudet V, Hanni C(2008) Molecular identification of vertebrate species by oligonucleotide microarray in food and forensic samples. J ApplEcol 45: 967-975.

16. Castresana $\mathrm{J}$ (2001) Cytochrome b phylogeny and the taxonomy of great apes and mammals. Mol Biol Evol 18: 465-471.

17. Verma SK, Singh L (2003) Novel universal primers establish identity of an enormous number of animal species for forensic application. Mol Ecol Notes 3:28-31.

18. An J, Lee MY, Min MS, Lee MH, Lee H (2007) A molecular genetic approach for species identification of mammals and sex determination of birds in a forensic case of poaching from South Korea. Forensic Sci Int 167: 59-61.

19. Wasser SK, Mailand C, Booth R, Mutayoba B, Kisamo E, et al. (2007) Using DNA to track the origin of the largest ivory seizure since the 1989 trade ban. Proc Natl Acad Sci U S A 104: 4228-4233.

20. Dooley JJ, Sage HD, Clarke MA, Brown HM, Garrett SD (2005) Fish species identification using PCR-RFLP analysis and lab-on-a-chip capillary electrophoresis: application to detect white fish species in food products and an interlaboratory study. J Agric Food Chem 53: 3348-3357.

21. Felsenstein J (1985) Confidence limits on phylogenies: an approach using the bootstrap. Evolution 39:783-791. 